\title{
Phytoplankton community of Reis lake in the Brazilian Amazon
}

\author{
ISE G. SILVA ${ }^{1}$, ARIADNE N. MOURA ${ }^{2}$ and ENIO W. DANTAS ${ }^{3}$ \\ ${ }^{1}$ Universidade Federal de Roraima, Instituto Insikiran de Formação Superior Indígena, \\ Av. Ene Garcez, 2413, Aeroporto, 69304-000 Boa Vista, RR, Brasil \\ ${ }^{2}$ Universidade Federal Rural de Pernambuco, Departamento de Biologia, \\ Área de Botânica, R. Dom Manoel de Medeiros, s/n, Dois Irmãos, 52171-030 Recife, PE, Brasil \\ ${ }^{3}$ Universidade Estadual da Paraíba, Departamento de Ciências Biológicas, \\ R. Horácio Trajano de Oliveira, s/n, Cristo, 58070-450 João Pessoa, PB, Brasil
}

Manuscript received on April 12, 2012; accepted for publication on July 16, 2012

\begin{abstract}
Reis Lake is located in the municipality of Caracaraí, state of Roraima (Brazil) and is subject to fluctuations in water level. The aim of this study was to analyze the structure of the phytoplankton community on the nictemeral and seasonal scales and determined the influence of limnological variables. Sampling was performed in the rainy season (June/2006) and dry season (November/2006), considering two nictemeral cycles. The phytoplankton community was assessed with regard to composition and density, abiotic variables were analyzed simultaneously. The lake had low concentrations of oxygen, clinograde profile and water stratified during the day and homogenous at night, with low concentrations of nutrients and waters ranging from slightly acidic to alkaline. The phytoplankton was represented by 43 taxa, 35 species in the dry season and 29 species in the rainy season. Low densities of phytoplankton occurred in both nictemeral cycles, with accentuated vertical gradient. The highest densities were recorded in the dry season. Reis Lake exhibits characteristics that classify it as a polymythic and oligotrophic environment. The variability in the data was more important seasonally than on the nictemeral scale, supporting the hypothesis of the influence of the hydrological cycle on the dynamics of phytoplankton communities in floodplain lakes.
\end{abstract}

Key words: phytoplankton, nictemeral, floodplain, seasonal, state of Roraima.

\section{INTRODUCTION}

Brazilian Amazon has a hydrographic basin with a large variety of aquatic systems distinguished by their combination of physical, chemical and biological characteristics. Some lakes located in depressions of the Boa Vista Formation are generally small and isolated from large and medium-sized rivers (Silva et al. 2010). In these areas, lakes generally have clear waters that may

Correspondence to: Ariadne do Nascimento Moura

E-mail: ariadne_moura@hotmail.com be either occupied by different species of aquatic macrophytes and filamentous algae or deprived of vegetation (Filho et al. 1997).

The area drained by the Branco River basin creates numerous lakes that are characterized by remaining connected to the river during the flood period and becoming isolated in the dry season. These lakes are used by the surrounding population, mainly for fishing or for recreation. Although the importance of studies in floodplain lakes is recognized for understanding the ecology 
of these environments and the river systems to which they are linked, surveys in floodplain lakes in the Brazilian Amazon are still punctual (Melo and Huszar 2000, Melo et al. 2004). Hydrographic and hydrological characteristics are suggested as being the factors that determine the behavior of the phytoplankton of these lakes.

The effects of water-level fluctuations as a major factor in the composition and dynamics of phytoplankton communities in floodplain lakes have been discussed by several authors (Ganf 1974, Ibañez 1998, Barbieri et al. 1989, Nabout et al. 2006).

Precipitation, wind and water-level fluctuations may be much more relevant than light and temperature on seasonal patterns of phytoplankton in tropical lakes. In the Albuquerque Lake (Pantanal Matogrossense) the highest phytoplankton densities were observed in low water periods and lower densities were observed during high waters, as a consequence of the availability of nutrients and light that are also influenced by variation in water level (Espíndola et al. 1996).

The algal community is considered a good indicator of the changes that occur in an aquatic environment due to its rapid response to short time intervals, especially regarding reproductive processes. Thus, knowledge of the structure and functioning of these biological communities, as well as their interaction with the physical environment become essential for understanding the behavior of these environments, aiming to achieve the sustainable use of resources and access to future generations.

Based on the hypothesis that spatial and temporal patterns of phytoplankton in floodplain lakes are influenced by fluctuations in abiotic variables as a result of variation in the water level in these environments, this study aimed to characterize a lake ecosystem of the floodplain of the Branco River, in the Brazilian Amazon, with regard to the composition and dynamics of the phytoplankton community and the influence of environmental variables on this community during the period of high waters (rainy) and low waters (dry).

\section{MATERIALS AND METHODS}

Reis Lake $\left(01^{\circ} 30^{\prime} 59,1^{\prime \prime} \mathrm{N}\right.$ e $\left.61^{\circ} 15^{\prime} 50,4^{\prime \prime} \mathrm{W}\right)$ is located on the right bank of the Branco River, in Caracaraí, southern region of the state of Roraima, in the Brazilian Amazon. It has an area of approximately 19.2 ha and, since it is connected to the Branco River, it exhibits high water-level fluctuation, reaching a maximum depth of about $8 \mathrm{~m}$ during high waters and a minimum depth of $1.5 \mathrm{~m}$ during low waters. The lake has slightly dark waters and its margins are well-preserved.

Based on the Köppen-Geiger classification, the state of Roraima pertains to the climatic group A (humid tropical). The rainfall pattern is represented by two rather distinct periods: a rainy season (April to September) and a dry season (October to March) (Silva et al. 2010).

Water samples for nutrient analysis and the investigation of the phytoplankton community (taxonomic and density studies) were collected at the same time and with two repetitions with a vertical Van Dorn bottle with a 3L of capacity at a central station in the lake over 24-hour sampling periods from the subsurface, middle of the water column and approximately $30 \mathrm{~cm}$ above the bottom. Samples $(n=2)$ were taken at four-hour intervals for a total of seven collections per period (Noon, 4 p.m., 8 p.m., 12 a.m., 4 a.m., 8 a.m. and midnight). Sampling was performed in the rainy season (June 2006) and dry season (November 2006).

Abiotic variables were determined in situ and included water temperature and dissolved oxygen (Schott Glaswerke Mainz, handylab OX1); conductivity and total dissolved solids (TSD) (Schott Glaswerke Mainz, handylab LF1); turbidity (Hanna Instruments, HI 93703), pH (Digimed, 
DMPH-2) and water transparency (Secchi disc 25 $\mathrm{cm}$ in diameter). For the determination of dissolved and total nutrients, water aliquots were placed in 300-mL polyethylene flasks and kept refrigerated until analysis. Samples were filtered through 47-mm AP20 glass multi-pore filters for the determination of dissolved nutrients. Non-filtered aliquots were used for the determination of total nutrients. Analysis to determine concentrations of total nitrogen $\left(\mu \mathrm{mol}\right.$.TN.L $\left.{ }^{-1}\right)$, nitrite $(\mu \mathrm{mol} . \mathrm{N}$ $\mathrm{NO}_{2} \cdot \mathrm{L}^{-1}$ ) and nitrate $\left(\mu \mathrm{mol} \cdot \mathrm{N}-\mathrm{NO}_{3} \cdot \mathrm{L}^{-1}\right.$ ) followed the procedures described by Valderrama (1981), Mackereth et al. (1978) and Golterman et al. (1978), respectively. Total phosphorus ( $\mu$ mol.TP.L ${ }^{-}$ ${ }^{1}$ ) and total dissolved phosphorus ( $\mu$ mol.TDP.L ${ }^{-1}$ ) were determined following Valderrama (1981). Orthophosphate $\left(\mu \mathrm{mol} . \mathrm{P}-\mathrm{PO}_{4} \cdot \mathrm{L}^{-1}\right)$ was determined following Strickland and Parsons (1965).

The Carlson Trophic State Index adapted by Toledo Jr. et al. (1983) for tropical regions was used for the trophic characterization of the ecosystem. Calculations were based on values of chlorophyll a, Secchi depth, total phosphorus and orthophosphate. Ultra-oligotrophic $(\leq 20)$, oligotrophic (21 to 40 ), mesotrophic (41 to 50), eutrophic (51 to 60) and hypertrophic $(\geq 61)$ conditions were then determined (Kratzer and Brezonik 1981).

Samples for taxonomic and density analyzes $(n=2)$ were preserved in acetic Lugol's solution. Morphometric features of the reproductive and vegetative phases were analyzed under a Zeiss microscope (model Axioskop) equipped with a light chamber, photographic camera and ocular with a measurement grid. Those specimens for which identification was not possible were considered phytoflagellates. The samples were added to the collection at the Professor Vasconcelos Sobrinho Herbarium of the Universidade Federal Rural de Pernambuco.

Densities (individuals per microliter) were estimated based on the method described by Utermöhl (1958), using an inverted microscope
(Zeiss, Axiovert). Organism counts were carried out with two repetitions for each depth sampled; the values are presented as the mean of the repetitions. The calculations were carried out based on the method described by Villafaiñe and Reid (1995). Dominant and abundant species were determined based on the concepts described by Lobo and Leighton (1986), for which a dominant species is that which surpasses $50 \%$ of the total phytoplankton density and an abundant species is that with a density value greater than the mean value of the community. The values are presented as the mean of the repetitions.

Analysis of variance (ANOVA) was used with a $5 \%$ level of significance to determine the degree of temporal variation (time of day, season), seasonal period and spatial variation (depth). Tukey's multiple comparison test was used to identify where differences were expressed in time and space. Analyses were performed using the Statistica 2004 software program (StatSoft, Inc., Tulsa, OK, USA). The Shannon-Wiener diversity index (H', bits/ind) was calculated (Shannon and Weaver 1948); Evenness was assessed based on the $\mathrm{H}^{\prime}$ of the Shannon-Wiener index. Canonical correspondence analysis (CCA) was used to determine correlations between biotic and abiotic variables. In the multivariate analysis, the matrix with biotic data was constructed with abundant and dominant species and the abiotic variables were log-transformed (x). The CANOCO 4.5 program (license number CAN6346) was used for the statistical analysis.

\section{RESULTS}

The thermal structure of the water of Reis Lake during the dry period is characterized by a system with stratified surface layers during the day (thermal variation from 1.1 to $3.5^{\circ} \mathrm{C}$ ) and homogenization at night until the early hours of the morning. During the rainy period the water column is completely unstratified at all sampled hours (Table I). 
The highest concentrations of dissolved oxygen were observed in the dry season $(\mathrm{F}=$ 129.602, $\mathrm{p}<0.001$ ), characterized by a clinograde profile in most of the sampled hours. The water column was homogeneous with low dissolved oxygen concentrations during the rainy season.

The $\mathrm{pH}$ values were stable (6.90) in the rainy season and showed a low amplitude in the dry season with values close to neutral and slightly alkaline. Electrical conductivity $(\mathrm{F}=57.08, \mathrm{p}$ $<0.01)$ and turbidity $(\mathrm{F}=2,378.85, \mathrm{p}<0.01)$ were more pronounced during the rainy season, where turbid waters were observed in the subsurface $(\mathrm{F}=100.07, \mathrm{p}<0.01)$ (Table I). Water transparency was low during the two nictemeral cycles, ranging between $0.7 \mathrm{~m}$ and $1.0 \mathrm{~m}$. The minimum value was found during the dry season $\left(\mathrm{Z}_{\max } 1.8 \mathrm{~m}\right)$ and the maximum value occurred during the rainy season $\left(Z_{\max } 8.0 \mathrm{~m}\right)$. The euphotic zone ranged from $2.1 \mathrm{~m}$ to $3.0 \mathrm{~m}$ in depth and comprised the entire water column during the dry season.

The Reis Lake was characterized by low nutrient concentrations. Total nitrogen, nitrate and nitrite showed similar nictemeral variation patterns, with slightly larger values toward the bottom (Tukey $\mathrm{p}<0.05$ ) in both seasons and irregular oscillations over the hours, especially during the dry season $(\mathrm{p}<0.05)$ (Table I).

The concentrations of total phosphorus and total dissolved phosphorus were higher in deeper layers (Tukey $p<0.05$ ) in both seasons and in most of the sampled hours. Although no significant vertical differences were observed, concentration of orthophosphate showed a similar trend. The lowest concentrations of phosphorus elements in the rainy season $\left(\mathrm{F}_{\mathrm{TP}}=78.42\right.$ and $\mathrm{F}_{\mathrm{TDP}}=16.636$, $\mathrm{p}<0.01)$ significantly contributed to an increase in the TN:TP atomic ratio and a reduction in trophism. The ecosystem is characterized as limited by nitrogen (NT:PT $<12$ ratio), oligotrophic (IET $<41$ ) during the rainy season and generally mesotrophic in the dry season (Table I).
The phytoplankton community of Reis Lake during the study period was represented by 43 taxa, including Cyanophyta (11.6\%), Chlorophyta (51.2\%), Euglenophyta (16.3\%), Bacillariophyta (16.3\%), Chrysophyta (2.3\%) and Dinophyta (2.3\%) (Fig. 1).

The seasonal analysis showed the presence of 35 species in the dry season and 29 species in the rainy season. Chlorophyta and Bacillariophyta had the largest number of species in the dry season (17 spp and 6 spp, respectively) (Table II).

Of the taxa surveyed, 14 were abundant during the two nictemeral cycles. Chlorophyta contributed with four species, Bacillariophyta with four, Cyanophyta with three, and Chrysophyta and Euglenophyta with one species. The species Tabellaria sp. (Bacillariophyta) and Phormidium sp. (Cyanophyta) as well as the phytoflagellates were dominant throughout the study (Table III).

The pattern of distribution of phytoplanktonic density was characterized by the formation of well-defined vertical gradients, with higher values at the subsurface and lower ones in the deeper layers of the lake. Regarding seasonal variation, the rainy season was characterized by having low densities, while the highest densities occurred in the dry season.

Bacillariophyta contributed with $57.3 \%$ of the total density, and Tabellaria sp was primarily responsible for this contribution. This species was present only during the period of low waters and its distribution in the water column showed small variations, with higher densities occurring usually at the subsurface. The pattern of distribution of Bacillariophyta was the inverse to other groups, in which the highest densities occurred in the deeper layers.

Chlorophyta accounted for $16.1 \%$ of the total density. The most representative species were Monoraphidium contortum (Thuret) KomárkováLegnerová (23.5\%) and Scenedesmus quadricauda (Turpin) Brébisson (32.9\%). 


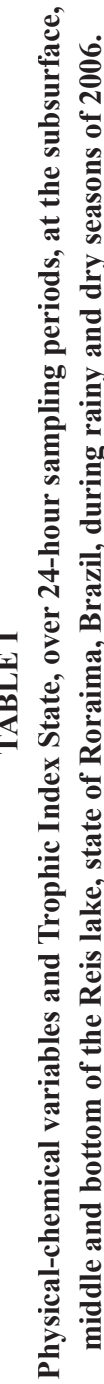

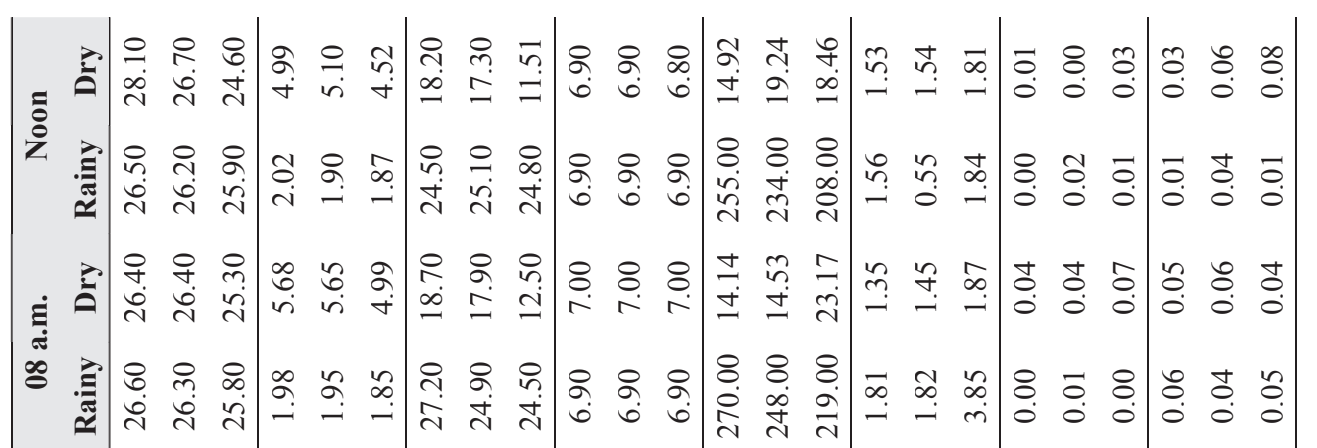

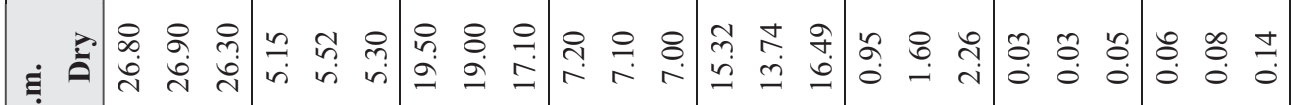

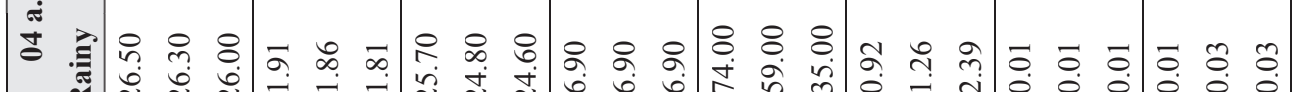

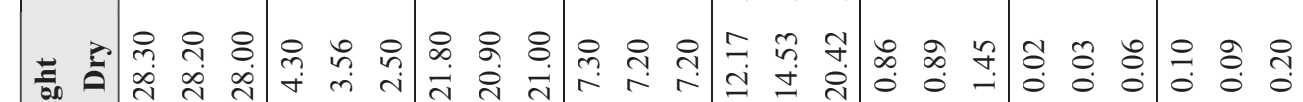

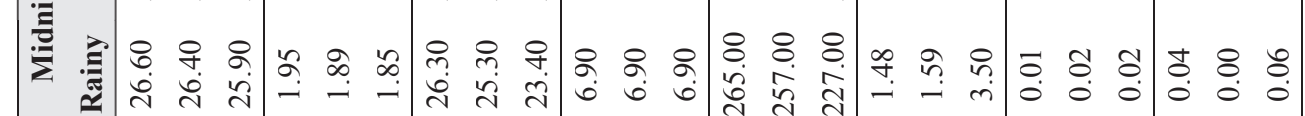

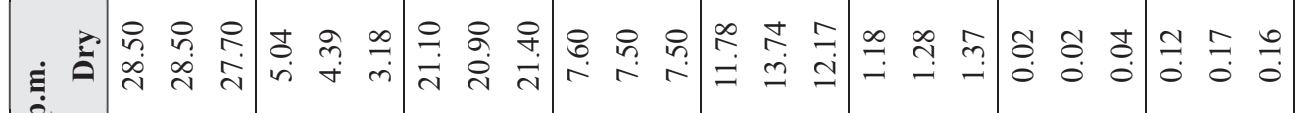
完

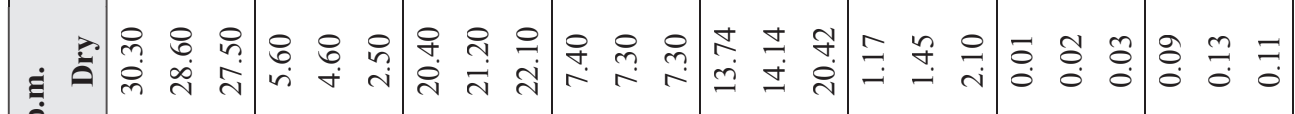

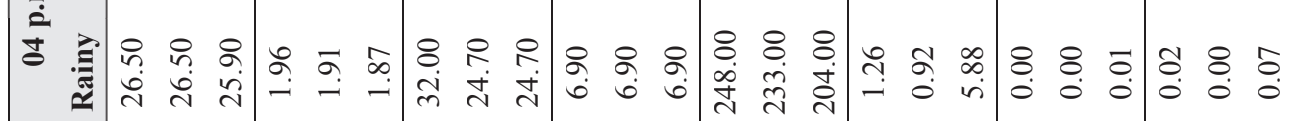

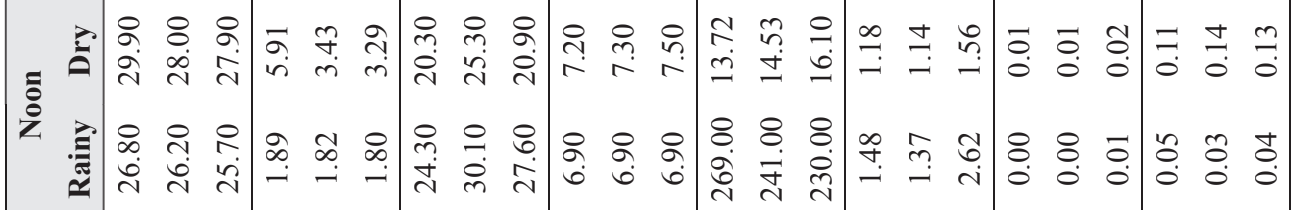

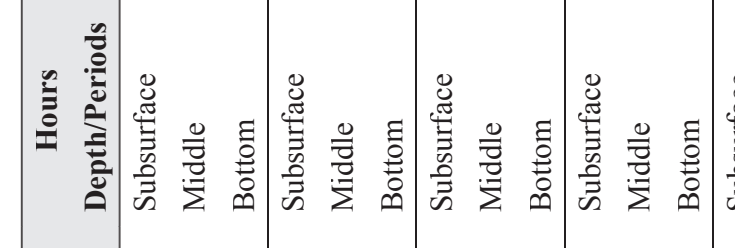

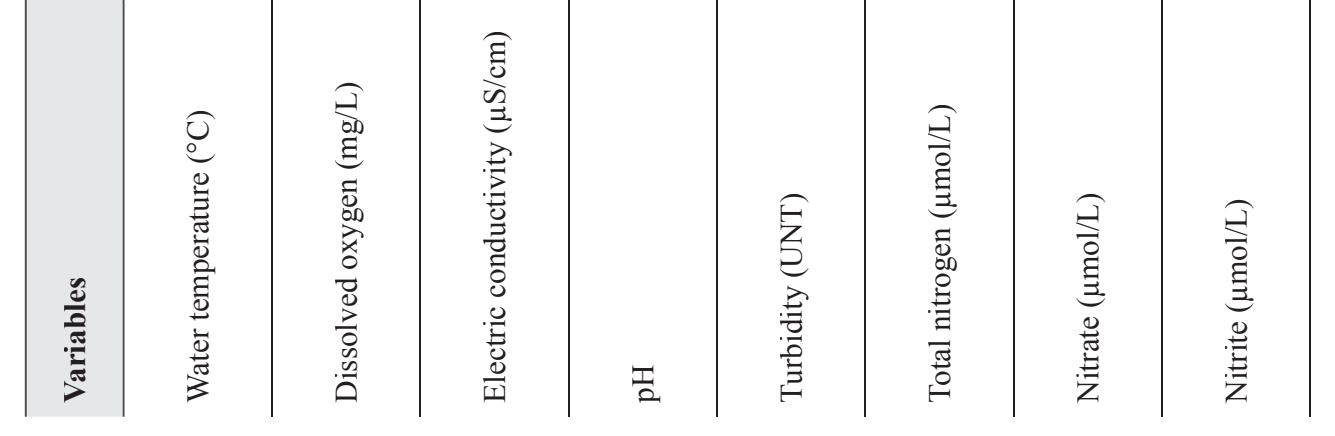




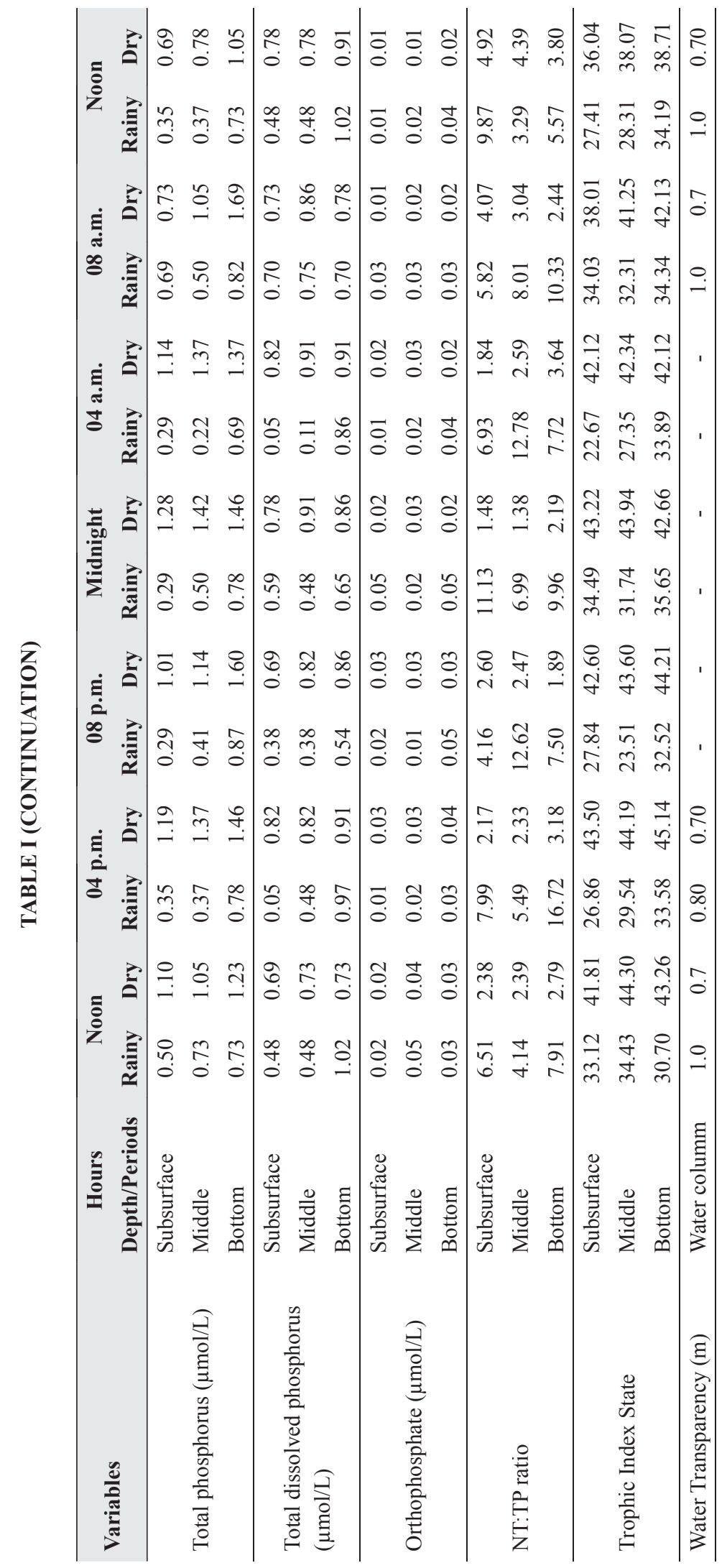




\section{A}

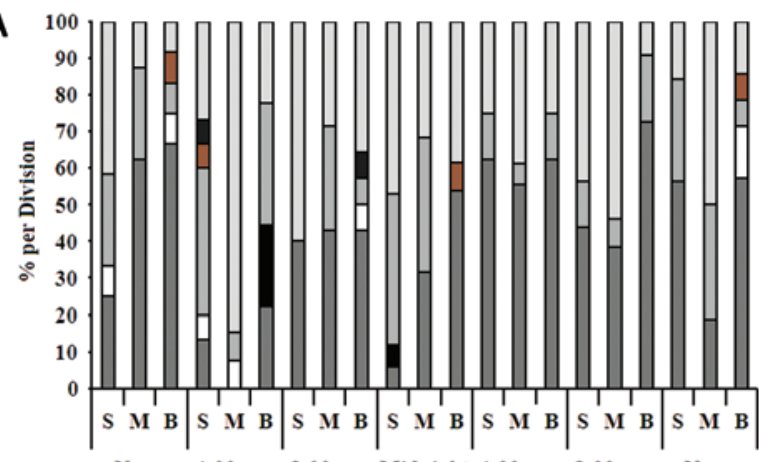

Noon 4:00 p.m 8:00 p.m Midnight 4:00 a.m 8:00 a.m Noon

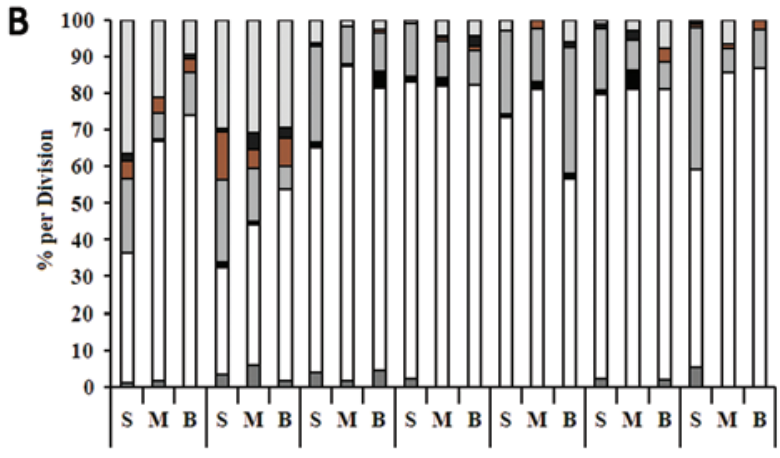

Noon 4:00 p.m 8:00 p.m Midnight 4:00 a.m 8:00 a.m Noon

$\square$ Cyanophyta $\square$ Bacillariophyta Chrysophyta $\square$ Chlorophyta

$\square$ Euglenophyta $\square$ Dinophyta $\square$ Phytoflagellates

Figure 1 - Nictemeral and Seasonal variations in the relative density of phytoplankton groups (\%) on the Reis Lake, state of Roraima, Brazilian Amazon. A: rainy period: June/2006 and B: dry period: November/2006).

TABLE II

Phytoplanktonic species registered at Reis Lake, State of Roraima, during rainy and dry seasons of 2006. (R: Rainy season; D: Dry season).

\begin{tabular}{|c|c|c|}
\hline Species $\backslash$ Seasons & $\mathbf{R}$ & $\mathbf{D}$ \\
\hline \multicolumn{3}{|l|}{ Bacillariophyta } \\
\hline Aulacoseira granulata (Ehrenberg) Simonsen & + & + \\
\hline Aulacoseira granulata var. angustissima (O. Müller) Simonsen & - & + \\
\hline Aulacoseira herzogii (Lemmermann) Simonsen & + & - \\
\hline Melosira varians Agardh & + & + \\
\hline Pinnularia maior (Kützing) Cleve & + & + \\
\hline Tabellaria sp. & - & + \\
\hline Urosolenia eriensis (H. L.) Round \& Crawf & - & + \\
\hline \multicolumn{3}{|l|}{ Chlorophyta } \\
\hline Acutodesmus acuminatus (Lagerheim) Tsarenko & + & + \\
\hline Ankistrodesmus gracilis (Reinsch) Korshikov & - & + \\
\hline Bambusina sp. & + & - \\
\hline Chlorococcun sp. & + & + \\
\hline Closterium sp. & + & + \\
\hline Cosmarium sp. & + & - \\
\hline Crucigenia fenestrata (Schmidle) Schmidle & - & + \\
\hline Desmodesmus denticulatus(Lagerheim) S. S. An, T. Friedl \& E. Hegewald & - & + \\
\hline Dictyosphaerium pulchellum H. C. Wood & + & + \\
\hline Golenkinia paucispina West \& West & - & + \\
\hline Gonatozygon monotaenium Bary in Rabenhorst & + & - \\
\hline Kirchneriella lunaris (Kirchner) K. Möbins & + & + \\
\hline Monoraphidium arcuatum (Korshikov) Hindák & + & + \\
\hline Monoraphidium contortum (Thuret) Komárková-Legnerová & + & + \\
\hline
\end{tabular}


TABLE II (CONTINUATION)

\begin{tabular}{|c|c|c|}
\hline Species $\backslash$ Seasons & $\mathbf{R}$ & $\mathbf{D}$ \\
\hline \multicolumn{3}{|l|}{ Chlorophyta } \\
\hline Monoraphidium griffithii (Berkeley) Komárková-Legnerová & + & + \\
\hline Nephrocytium agardhianum Nägeli & + & - \\
\hline Oocystis lacustris Chodat & + & - \\
\hline Pediastrum tetras (Ehrenberg) Ralfs & - & + \\
\hline Scenedesmus quadricauda ( Turpin) Brébisson & - & + \\
\hline Scenedesmus sp. & + & + \\
\hline Sphaerocystis shroeteri Chodat & + & + \\
\hline Treubaria triappendiculata C. Bernard & + & + \\
\hline \multicolumn{3}{|l|}{ Cyanophyta } \\
\hline Aphanocapsa sp. & + & - \\
\hline Chroococcus minor (Kützing) Nägeli & + & + \\
\hline Merismopedia tenuissima Lemmermann & + & + \\
\hline Oscillatoria sp. & + & - \\
\hline Phormidium sp. & + & + \\
\hline \multicolumn{3}{|l|}{ Chrysophyta } \\
\hline Dinobryon sertularia Ehrenberg & + & + \\
\hline \multicolumn{3}{|l|}{ Euglenophyta } \\
\hline Euglena sp. & + & + \\
\hline Lepocinclis ovum (Ehrenberg) Lemmermann & - & + \\
\hline Phacus acuminatus A. Stokes & - & + \\
\hline Phacus cf. suecicus Lemmermann & - & + \\
\hline Phacus curvicauda Svirenko & + & + \\
\hline Phacus longicauda (Ehrenberg) Djardin & - & + \\
\hline Strombomonas cf. acuminatus (Schmarda) De Flandre & - & + \\
\hline \multicolumn{3}{|l|}{ Dinophyta } \\
\hline Peridinium sp. & + & + \\
\hline
\end{tabular}

The phytoflagellates were the third most important group, quantitatively, accounting for $15.3 \%$ of the total density.

The specific diversity was variable between hours and depths, with low, medium and high values. The equitability values in the Reis Lake were mostly below 0.5 , characterizing a nonuniform distribution of the species (Fig. 2).

The results of the CCA analysis are summarized in Table IV and Figure 3. The CCA indicated that the eigenvalues of axes 1 and 2 explained
$44.4 \%$ of the variance of the biotic data. The Monte Carlo test was significant ( $\mathrm{p} \leq 0.05)$, indicating the impossibility that the data were sorted randomly. Environmental variables explained $51.9 \%$ of the variability and $85.4 \%$ of the explanation was summarized by the first two axes. Pearson correlation indicated a strong correlation between the phytoplankton community and environmental variables.

The CCA showed a clear seasonal difference. The sampling units related to the rainy season were 
PHYTOPLANKTON COMMUNITY OF FLOODPLAIN LAKE

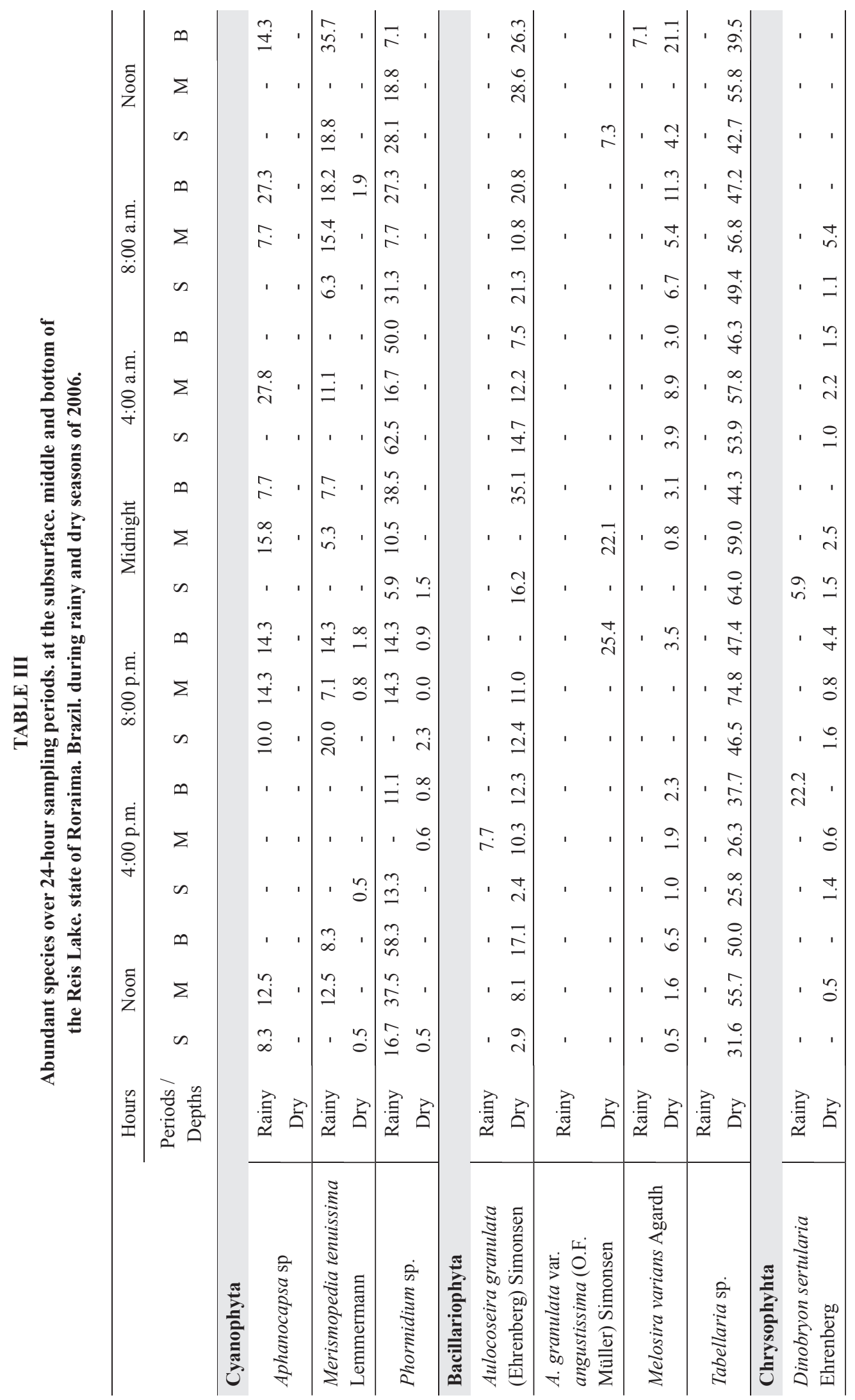




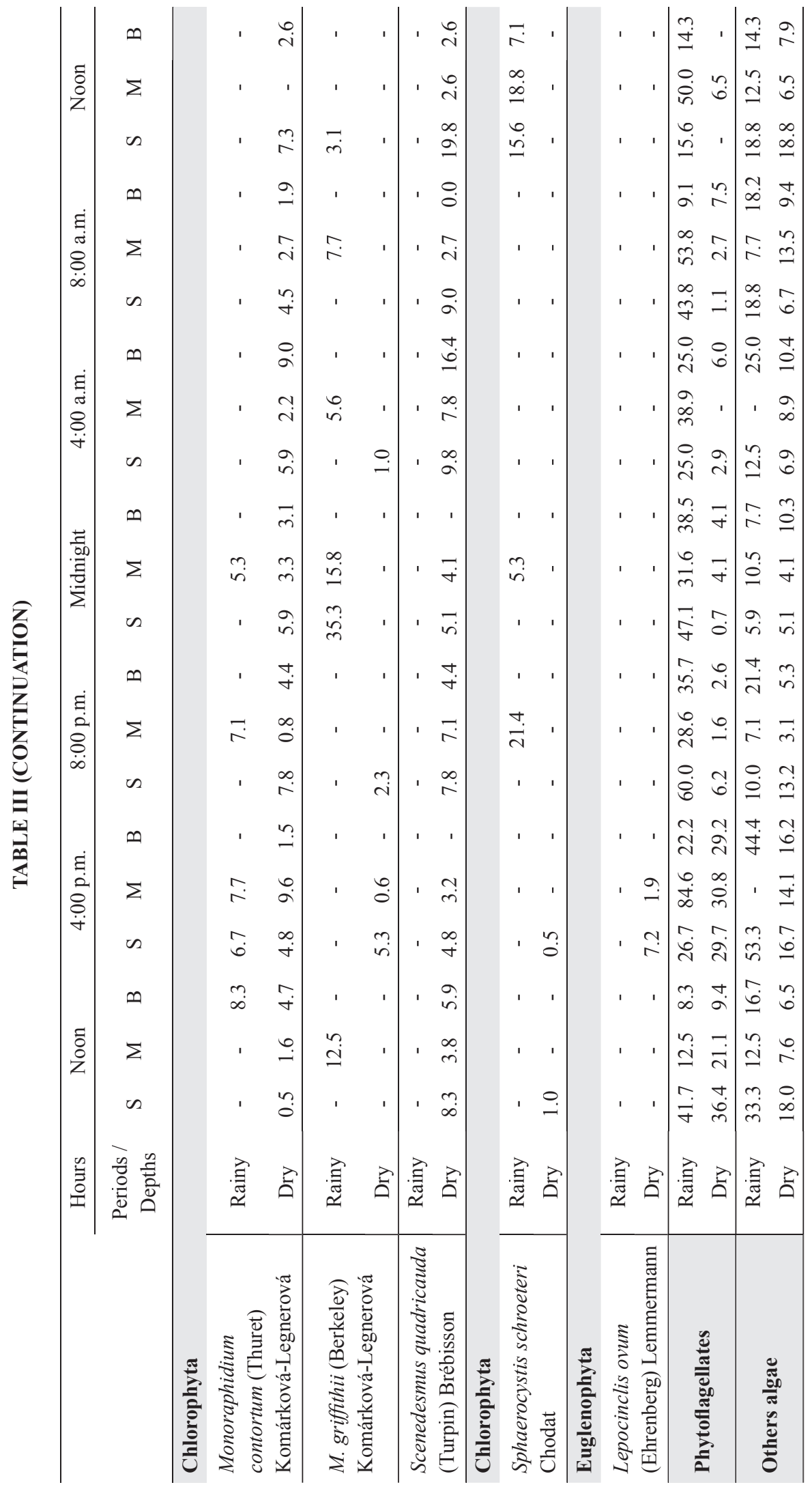


A

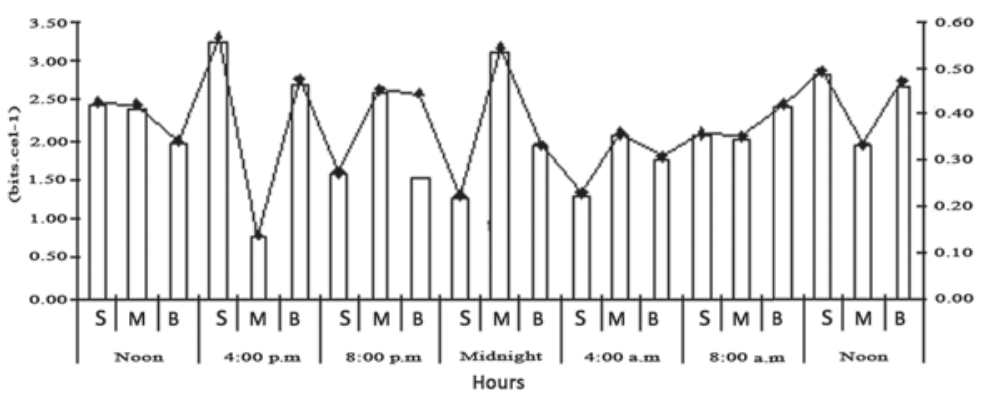

$\square$ Diversity $\rightarrow$ Equitability

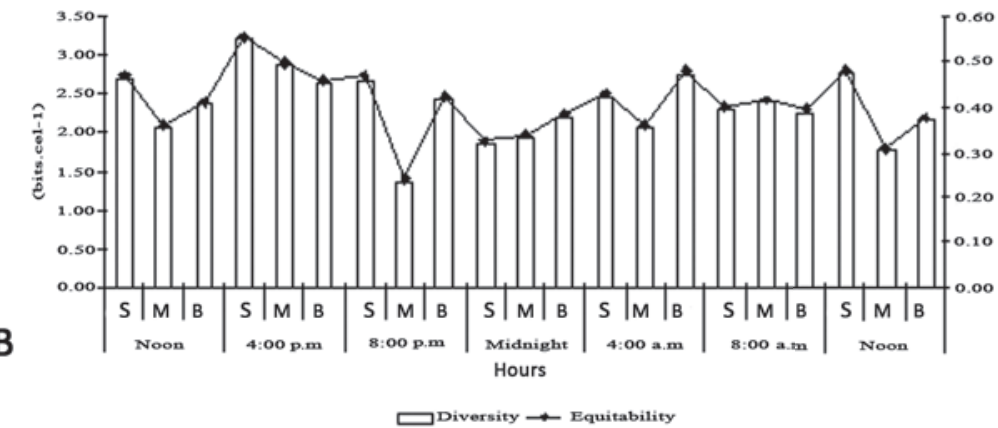

Figure 2 - CCA ordination of the samples showing the correspondence of abundant algae and abiotic variables in Reis Lake, Brazil. The units are identified based on times of the day (Noon, 4 p.m., 8 p.m., Midnight, 4 a.m., 8 a.m. and Noon); symbols indicate season (rainy, dry) and sampling depth (subsurface, middle, bottom); Abbreviations: Cond=electric conductivity; $\mathrm{NO}_{2}=$ nitrite; $\mathrm{NO}_{3}=$ nitrate; $\mathrm{O}_{2}=$ dissolved oxygen; $\mathrm{pH}=\mathrm{pH} ; \mathrm{T}^{\circ} \mathrm{C}=$ water temperature; $\mathrm{TDP}=$ total dissolved phosphorus; $\mathrm{TN}=$ total nitrogen; TP = total phosphorus; Turb = turbidity; Aga = Aulacoseira granulata var. angustissima; Agr = A. granulata; Asp = Aphanocapsa sp.; Dse = Dinobryon sertularia $;$ Lov = Lepociclis ovum; Mco = Monoraphidium contortum; Mgr = M. griffithii; $\mathrm{Msv}=$ Melosira varians; Mte = Merismopedia tenuissima $;$ Phy $=$ phytoflagellates $;$ Psp $=$ Phormidium $\mathrm{sp} . ;$ Squ $=$ Scenedesmus quadricauda; $\mathrm{Ssc}=$ Sphaerocystis schroeteri; $\mathrm{Tsp}=$ Tabellaria $\mathrm{sp}$.

positively associated with axis 1 and corresponded to high values of turbidity and electrical conductivity. The species associated with axis 1 and related to the rainy season were Aphanocapsa sp., Monoraphidium griffithii (Berkeley) Komárková-Legnerová, Merismopedia tenuissima Lemmermann, Phormidium sp., Sphaerocystis schroeteri Chodat and phytoflagellates. The sample units of the dry season were negatively associated with this axis and corresponded to high values of $\mathrm{pH}$, dissolved oxygen and nutrients. The species associated with the dry season were Aucoloseira granulata (Ehrenberg) Simonsen, A. granulata var. angustissima (O. Müller) Simonsen, Dinobryon sertularia Ehrenberg, Melosira varians C. Agardh, Monoraphidium contortum (Thuret) Komàrková-Legnerová, Scenedesmus quadricauda Chodat and Tabellaria sp.

In axis 2, water temperature and total nitrogen were the most important variables in the intra-set correlations, related to the axis in positive and negative ways, respectively. The sampling units ordered by this axis showed vertical variation, the samples being collected at the subsurface on the positive side and at the bottom in the opposite direction. Lepocinclis ovum (Ehrenberg) Lemmermann was the taxon most closely related to this axis, occurring especially in the dry season and in the superficial layers of the lake. 

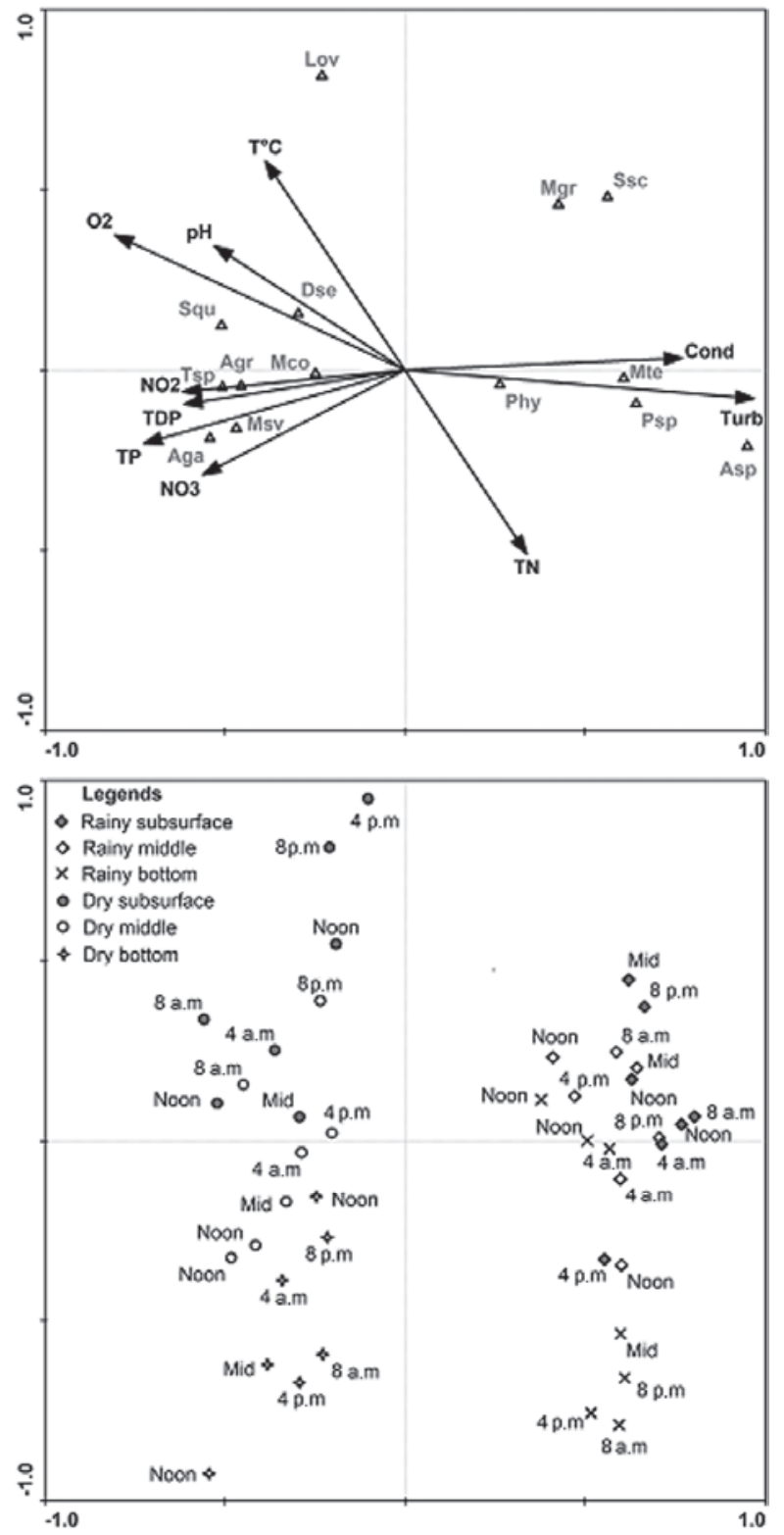

Figure 3 - Nictemeral and Seasonal variations in species diversity (bits.cel.-1) and equitability in Reis Lake, state of Roraima, Brazil. (A: diversity and equitability on 21 and 22 June 2006, rainy; B: diversity and equitability on 13 and 14 November 2006, dry).

\section{DISCUSSION}

The flood pulse is the main force responsible for nutrient dynamics, changes in the structure of aquatic communities, as well as the way in which humans occupy and exploit the floodplains (Junk et al. 1989).
According to Forsberg et al. (1988) the lakes of the Amazon floodplain receive water and nutrients primarily from two sources: the local watershed and the main river, and the seasonal variations in water level can cause large changes in the area and depth of these lakes.

The water level fluctuation of the Branco River caused by seasonal variation is a main factor in determining the ecological processes of the Reis Lake. Large oscillations in the volume and depth of the lake directly influence the dynamics of the limnological variables and biota. The thermal stability of the water column during the low water period was probably responsible for the distribution pattern of dissolved oxygen that exhibited a clinograde profile. These conditions also influenced the dynamics of nutrients, contributing to accumulation events in the deeper layers. These events can lead to limitations in nitrogen and high phosphorus concentrations, confirmed by the low $\mathrm{NT}$ :PT ratio found in the lake.

The environmental characteristics observed in the Reis Lake corroborate Tundisi et al. (1984) who associated the depletion of dissolved oxygen and nutrient accumulation in the deeper layers of two Amazonian lakes to their thermal stratification. In the same way, the behavior of the abiotic conditions of the Reis Lake confirms the findings by Esteves et al. (1994) for Batata and Mussurá Lakes, two floodplain lakes of the Trombetas River basin (state of Pará), where the thermal behavior was responsible for the homogeneous vertical distribution of $\mathrm{pH}$, conductivity and dissolved oxygen.

The distribution of phytoplankton in the water column is strongly influenced by the physicalchemical conditions of the water, such as light availability, temperature, turbulence, concentration of dissolved oxygen, and nutrients (Esteves and Suzuki 2011) that in turn exhibit significant temporal variations as a consequence of the flood pulse (Nabout et al. 2006). 
TABLE IV

Statistical summary and correlation coefficients for phytoplankton species and abiotic variables on the first two CCA axes for the Reis Lake, state of Roraima, Brazil.

\begin{tabular}{|c|c|c|c|c|}
\hline & & & Axis 1 & Axis 2 \\
\hline Eigenvalues & & & 0.496 & 0.051 \\
\hline Accumulated variance in biotic data $(\%)$ & & & 40.2 & 44.4 \\
\hline Accumulated variance in species-environment relation (\%) & & & 77.4 & 85.4 \\
\hline Species-environment correlation & & & 0.957 & 0.656 \\
\hline \multicolumn{5}{|l|}{ Monte Carlo test } \\
\hline Significance of first canonical axis $-p$ & & & 0.001 & \\
\hline \multirow[t]{3}{*}{ Significance of all canonical axes $-p$} & & & 0.001 & \\
\hline & \multicolumn{2}{|c|}{ Canonical coefficient } & \multicolumn{2}{|c|}{ Intra-set correlation } \\
\hline & Axis 1 & Axis 2 & Axis 1 & Axis 2 \\
\hline Water temperature & -0.37 & 0.38 & -0.39 & 0.58 \\
\hline Dissolved oxygen & -0.77 & 0.25 & -0.80 & 0.37 \\
\hline Electric conductivity & 0.74 & 0.02 & 0.77 & 0.03 \\
\hline $\mathrm{pH}$ & -0.51 & 0.23 & -0.53 & 0.34 \\
\hline Turbidity & 0.93 & -0.05 & 0.97 & -0.08 \\
\hline Total nitrogen & 0.32 & -0.33 & 0.34 & -0.51 \\
\hline Nitrate & -0.54 & -0.19 & -0.56 & -0.29 \\
\hline Nitrite & -0.59 & -0.04 & -0.62 & -0.06 \\
\hline Total phosphorus & -0.69 & -0.13 & -0.73 & -0.20 \\
\hline Total dissolved phosphorus & -0.59 & -0.06 & -0.61 & -0.10 \\
\hline
\end{tabular}

The temporal dynamics of the phytoplankton community in Reis Lake displayed fluctuations as a function of the hydrological pulse. The highest densities occurred in the dry season (low water) and the lowest in the rainy season (high water); factors such as turbidity and nutrient availability, were certainly responsible for these variations. This confirms the findings by Espíndola et al. (1996) who observed higher phytoplankton densities in the low water period and lower densities during high waters, sustaining that these differences were due to variations of light and nutrients, which were influenced by water level fluctuations. High densities in the low water period were also observed by Huszar (2000) for Batata Lake and by Pinilla (2006) for Boa Lake (Colombian Amazon). In Batata Lake, the incorporation of nutrients and frequent mixing of the water column during low waters influenced the increase in density. Other authors also discuss the influence of the flood pulse on the structure and composition of the phytoplankton community (Melo and Huszar 2000, Domitrovic 2003, Melo et al. 2004).

The high diatom densities observed in the deeper layers of the Reis Lake during the low water period are explained by their sedimentation ability, confirming the statement made by Esteves (1988).

The phytoplankton composition of the Reis Lake is similar to that found in other Amazonian lakes (Ibañez 1998, Huszar 1996, Melo and Huszar 2000, Echenique et al. 2004, Nabout et al. 2006, Souza et al. 2007) with Chlorophyta being the predominant group in most studies.

The canonical correspondence analysis showed that the variability of the data was more important seasonally than on the nictemeral scale, reinforcing the hypothesis that the hydrological cycle influences 
the dynamics of phytoplankton communities in floodplain lakes. In the rainy season, turbidity was responsible for the dynamics of the phytoplankton community, when the lowest densities were recorded. In the dry period, the variables dissolved oxygen, $\mathrm{pH}$, nitrate and phosphate influenced the temporal pattern of the community.

High densities of Aucoloseira granulata, Melosira varians, Tabellaria sp. (Bacillariophyta) and Phormidium sp. (Cyanophyta) as well as the phytoflagellates, were observed during the study.

\section{CONCLUSION}

The hydrological pulse was the determining factor in the dynamics of the phytoplankton community, particularly because it regulated the low values of turbidity and nutrient availability, and influenced the changes in the phytoplankton densities.

The highest densities were recorded in the dry season and the lowest densities were recorded in the rainy season. Reis Lake exhibited characteristics that classify it as a polymythic, oligotrophic environment. The analysis demonstrated that the variability in the data was more important seasonally than on the nictemeral scale, supporting the hypothesis that the hydrological cycle influences the dynamics of phytoplankton communities in floodplain lakes.

\section{ACKNOWLEDGMENTS}

The authors thanks Coordenação de Aperfeiçoamento de Pessoal do Ensino Superior (CAPES) and grants from CNPq (Brazilian Council for Research and Development) PQ.301715/20084 and 302068/2011-2 for ANM.

\section{RESUMO}

O lago dos Reis está localizado no município de Caracaraí, no estado de Roraima (Brasil) e está sujeito a flutuações no nível da água. O objetivo do estudo foi analisar a estrutura da comunidade fitoplanctônica nas escalas nictemeral e sazonal e determinar a influência de variáveis limnológicas nesta comunidade. As amostragens foram realizadas nos periodos chuvoso e seco, considerando dois ciclos nictemeral. A comunidade fitoplanctônica foi avaliada no que diz respeito à composição e densidade, simultaneamente, variáveis abióticas foram analisadas. O lago apresentou baixas concentrações de oxigênio, perfil clinogrado, coluna d' água estratificada durante o dia e homogênea à noite, com baixas concentrações de nutrientes e $\mathrm{pH}$ variarando de levemente ácido a alcalino. Baixas densidades fitoplanctônicas ocorreram em ambos os ciclos nictemeral, com um gradiente vertical acentuado. As maiores densidades foram registradas durante a estação seca e a menor foi registrada durante a estação chuvosa. Lago dos Reis apresenta características que o classificam como um ambiente polimítico e oligotrófico. A variabilidade dos dados foi mais importante sazonalmente do que na escala nictemeral, reforçando a hipótese da influência do ciclo hidrológico sobre a dinâmica das comunidades fitoplanctônicas em lagos de várzea.

Palavras-chave: fitoplâncton, nictemeral, lagos de várzea, sazonal, estado de Roraima.

\section{REFERENCES}

BARBIERI R, IBAÑEZ MSR, ARANHA FJ, CORREIA MMF, REID JW AND TURNER P. 1989. Plâncton, produção primária e alguns fatores físico-químicos de dois lagos da Baixada Maranhense. Rev Bras Biol 49: 399-408.

DOMITROVIC YZ. 2003. Effect of fluctuations in water level on phytoplankton development in three lakes of the Paraná river floodplain (Argentina). Hydrobiologia 510: 175-193.

ECHENIQUE RO, NúÑEZ-AvellanedA M AND DUQUE SR. 2004. Chlorococcales de la amazonia colombiana I: Chlorellaceae y Scenedesmaceae. Caldasia 26: 37-51.

ESPíndOLA EG, MATSUMURA-TUNDISI T AND MORENO ID. 1996. Estrutura da comunidade fitoplanctônica da lagoa Albuquerque (Pantanal Matogrossense), Mato Grosso do Sul, Brasil. Acta Limnol Bras 8: 13-37.

ESTEVES FA. 1988. Fundamentos de Limnologia. Interciência/ FINEP, Rio de Janeiro, $575 \mathrm{p}$.

Esteves FA AND SuZUKI MS. 2011. Comunidade Fitoplanctônica. In: Esteves, FA (Coord.). Fundamentos de Limnologia. $3^{\text {a }}$ ed., Rio de Janeiro: Editora Interciência, p. 375-445.

EsteVes FA, Thomaz SM AND Roland F. 1994. Comparison of the metabolism of two floodplain lakes of the Trombetas River (Pará, Brazil) based on study of diel variation. Amazoniana 13: 33-46. 
FILHO FS, TURCQ B, FILHO ACAND SOUZA AG. 1997. Registros sedimentares de lagos e brejos dos campos de Roraima: implicações paleoambientais ao longo do Holoceno. In: BARBOSA RI, FERREIRA EJG AND EG CASTELLÓN (Eds), Homem, Ambiente e Ecologia no Estado de Roraima. Manaus, INPA, p. 295-305.

Forsberg BR, Devol AHL, Richey AM AND SANTOS H. 1988. Factors contolling nutrient concentrations in Amazon floodplain lakes. Limnol Oceanogr 33: 41-56.

GANF GG. 1974. Diurnal mixing and the vertical distribution of phytoplakton in a shallow equatorial lake (Lake George, Uganda). J Ecol 62: 611-629.

Golterman HL, Clymo RS and Ohnstad MAM. 1978. Methods or physical and chemical analysis of freshwater. $2^{\text {nd }}$ ed., Oxford: Blackwell Scientific Publications, IBP handbook, $213 \mathrm{p}$.

HuSZAR VLM. 1996. Floristic composition and biogeographical aspects of phytoplankton of an Amazonian floodplain lake (Lago Batata, Pará, Brasil). Acta Limnol Bras 8: 127-136.

HusZAR VLM. 2000. Fitoplâncton. In: BOZELLI RL, ESTEVES FA AND ROLAND F (Eds), Lago Batata: impacto e recuperação de um ecossistema amazônico. Rio de Janeiro: UFRJ/SBL, p. 91-104.

IBAÑEZ MSR. 1998. Phytoplankton composition and abundance of a central Amazonian floodplain lake. Hydrobiologia 362: 78-83.

JunK WJ, BAYLEY PB AND SPARKS RE. 1989. The flood pulse concept in river-floodplain systems. Can Spec Publ Fish Aquat Sci 106: 110-127.

Kratzer CR AND BREzoniK PL. 1981. Carlson type trophic state index for nitrogen in Florida lakes. Water Resour Bull 17: 713-714.

Lobo E AND LEIGHTON G. 1986. Estructuras de las fitocenosis plantonicas de los sistemas de desembocaduras de rios e esteros de la zona central de Chile. Rev Biol Mar 22: 143-170.

MACKERETH JJH, HeRON J AND TALLING JF. 1978. Water analysis: some revised methods for limnologists. Kendall: Titus Wilson \& Son Ltd, Freshwater Biological Association, Scientific Publication n ${ }^{\circ} 36,117$ p.

Melo S AND Huszar VLM. 2000. Phytoplankton in an Amazonian flood-plain lake (Lago Batata, Brasil): diel variation and species strategies. J Plankton Res 22: 63-76.

Melo S, Huszar VlM, Roland F, Esteves FA AND BOZELLI R. 2004. Phytoplankton diel variation and vertical distribution in two Amazonian floodplain lakes (Batata Lake and Mussurá Lake, Pará-Brasil) with different mixing regimes. Amazoniana 18: 1-10.
NABout JC, NOGUEIRA IS AND OliveIRA LG. 2006. Phytoplankton community of floodplain lakes of the Araguaia River, Brazil, in the rainy and dry seasons. J Plankton Res 282: 181-193.

PINILLA GA. 2006. Vertical distribution of phytoplankton in clear water lake of Colombian Amazon (Lake Boa, Middle caquetá). Hydrobiologia, p. 79-90.

SHANNON CE AND WEAVER W. 1948. The mathematical theory of communication. Urbana, Illinois University Press, $117 \mathrm{p}$.

Silva IG, Moura NA, Dantas EW AND BittencourtOLIVEIRA MC. 2010. Structure and dynamics of phytoplankton in an Amazon lake, Brazil. Rev Biol Trop 4: 1421-1436.

Souza KF, Melo S AND Almeida FF. 2007. Desmídias de um lago de inundação do Parque Nacional do Jaú (Amazonas - Brasil). Rev Brasil Bioc 5: 24-26.

STRICKLAND JD AND PARSONS TR. 1965. A manual of sea water analysis. Bull Fish Res B Can 125: 1-185.

Toledo Jr AP, TAlarico M, Chinez SJ AND Agudo EG. 1983. A aplicação de modelos simplificados para a avaliação de processo da eutrofização em lagos e reservatórios tropicais. In: CONGRESSO BRASILEIRO DE ENGENHARIA SANITÁRIA E AMBIENTAL, Camboriú. Anais... Camboriú, p. 1-34.

Tundisi JG, Forsberg BR, DEVOl AH, ZARET TM, TUNDISI TM, DOS SANTOS A, RIBEIRO JS AND HARDY ER. 1984. Mixing patterns in Amazon lakes. Hydrobiologia 108: 3-15.

UTERMÖHL H. 1958. Zur vervollkommer der quantitativen phytoplankton methodik. Mitteilung Internationale Vereinigung fuer Theoretische und Amgewandte Limnologie 9: 1-38.

VALDERRAMA GC. 1981. The simultaneous analysis of total nitrogen and total phosphorus in natural waters. Marine Chemistry 10: 109-122.

VILlafañE VE AND REID FMH. 1995. Métodos de Microscopia para la Cuantificacion del Fitoplancton. In: ALVEAL K, FERRARO MEE, OLIVEIRA C AND SAR E (Eds), Manual de Métodos Ficológicos Universidad de Concepción - Concepción - Chile, 825 p. 